\section{Western help comes slowly}

\section{Laxenburg, Austria}

AN expert task force on the environment in Eastern Europe is urging governments and potential Western benefactors to concentrate first on so-called 'hot spots' that threaten public health before getting on with the monumental clean-up of polluted air, water and land in the region.

East European governments should focus their first efforts on building credible institutions for environmental protection equipped to enforce their policies before dealing with the problems.

The task force, which met last month at the International Institute for Applied Systems Analysis (IIASA) in Vienna, was the first meeting of scientific experts from all countries in the region. Its recommendations will be sent to East European environment ministers and potential donors and lenders such as the European Communities and the World Bank.

The overall picture of the environment that emerged at the meeting was unreENVIRONMENT

\section{New international organization}

\section{Paris}

Plans to establish an international environment group supported by 25 nations were approved at the World Bank headquarters in Paris last week.

The Global Environment Facility (GEF) which will have an estimated budget of more than $\$ 1,000$ million, will aim to promote "prudent environmental management", by encouraging 'green' technologies and strengthening policies put forward by individual countries.

The inspiration for GEF came from the French Finance Minister, Pierre Bérégovoy, with support from the German Federal Republic at the World Bank's annual meeting in September 1989. The Group should be running by the middle of next year.

The new organization will be implemented jointly by the World Bank, the United Nations Environment Programme (UNEP) and the United Nations Development Programme (UNDP).

It will cover four major areas: energy conservation and the limitation of greenhouse gas emission, preservation of areas with rich ecological diversity, protection of international waters from pollution and protection of the ozone layer.

According to the World Bank, GEF will provide practical experience in implementing environmentally sound programmes worldwide before the 1992 United Nations Conference on Environment and Development. Peter Coles mittingly grim. George Djolov, director of the Ecology Institute of the Bulgarian Academy of Sciences in Sofia, reported that 50,000 hectares of Bulgaria near nonferrous smelters had been so heavily polluted with heavy metals that, if US

\section{IMAGE UNAVAILABLE FOR COPYRIGHT REASONS}

International Institute for Applied Systems Analysis seeking to secure its future.

standards were applied, all children in the region would have to be taken to hospital for detoxification.

A report from Hungary indicated that drinking water in 20-25 per cent of the country's villages is contaminated so badly with nitrates that the authorities have to bring in water in plastic bags for babies.

Of the six countries represented, Poland has made the most progress in building the necessary institutions, such as an environment ministry and credible nongovernmental organizations, although the future is clouded by the recent demise of the government. The ministry is the first in Eastern Europe to outline a clear policy and to tell other ministries what they must do to fulfil environmental goals.

Poland is also the first to receive international help to clean up its environment. The World Bank in Washington has so far loaned $\$ 18$ million and the European Communities have singled out Poland and Hungary to receive environmental aid through the PHARE (Poland and Hungary Assistance to the Restructuring of Economics) programme. Together they will receive 49 million ECU $(\$ 35.5$ million)

But Western lenders are concentrating more on building up the economies of Eastern Europe than on the environment. A World Bank representative in Washington, Richard Ackermann, says that the bank is "increasingly saying that environmental issues cannot be settled until the economic issues are settled". And he adds, "The economic distortions in Eastern Europe are so enormous that it would be unwise to move in with massive investment" right away.

Although the World Bank is considering loaning as much as $\$ 7,000$ million by 1992 to all of Eastern Europe, Ackermann warns that the costs of environmental decontamination and protection are much higher than originally thought - the United States, by comparison, spent $\$ 640$ thousand million on the environment over the past nine years.

In every country but Bulgaria, the ecological opposition movements that helped to drive the Communists from power are losing support as economic concerns come to the fore. "[The [o environmentalists] no longer 总 have a common enemy", says Steve Wassersug of the Western-backed Regional Environment Centre in Budapest.

In Bulgaria, the opposition Eco-Glasnost movement continues to gather support, in part because it promises a foreign-funded clean-up. Djolov, calls this "a dangerous game" and says that the politicians "ought to know better. They're just creating illusions", he says, "and when these fail, we will have to pay the costs." He adds, "The sooner we realize that we are on our own, the better".

Those at the meeting who looked to the clean-up of the former East Germany to provide an exemplar for the rest of Eastern Europe were disappointed by the harsh picture presented by German government representatives. "The lack of functional enforcement agencies will be a major problem" in Eastern Europe, says Hans-Joachim Hermann of the Federal Environment Office in Berlin. Unlike other countries, Germany is not dependent on the worst industrial polluters for its economic well-being, says Hermann. This means it can order compliance with strict Western standards by 1996 or else shut down the plants.

In fact, Germany is counting on shutting down the worst offenders as the fastest way to reduce harmful emissions in its Eastern reaches. Of a ten per cent decrease in sulphur dioxide emissions reported so far in eastern Germany, four-fifths is a result of shutdowns, says Hermann.

A further disappointment to other countries is Germany's decision to take what it euphemistically describes as a "pragmatic" approach to toxic wastes. The state will nominally take responsibility for toxic-waste dumps in the East, absolving investors of financial responsibility for cleaning them up.

But this does not mean that the state will clean up the dumps. Instead, it is more likely just to "put a fence around" the waste sites except where they have been proved hazardous to the health of the local population, says Hermann. "We don't even have a fund to clean up toxic wastes in the western part of Germany", he says. "You can't demand that standards be higher in the East."

Steven Dickman 